\title{
O elogio de Sócrates por Alcibíades ${ }^{1}$
}

Roberto Bolzani Filho - Universidade de São Paulo

Em sua tradução comentada do Banquete, R. E. Allen oferece uma razão para a presença de Alcibíades nos momentos finais do diálogo, quando este chega, embriagado, irrompendo sem ser convidado:

Alcibíades está interessado em louvar Sócrates, mais
do que a Eros. Teria sido uma afronta à modéstia e in-
decoroso fazer Sócrates narrar semelhante elogio de si
próprio. Isso ajuda a explicar também a introdução de
Diotima, pois seria difícil fazer Sócrates oferecer um
elogio de Eros, que, quando Alcibíades o louvar, fará
com que o próprio Sócrates esteja nele representado...
O retrato platônico de Sócrates no Banquete é uma po-
derosa defesa de Sócrates. Não se poderia fazer com
que o próprio Sócrates narrasse tais coisas, mas era ne-
cessário dizê-las; Platão o consegue, fazendo com que
o próprio Alcibíades as diga - e deixando Aristodemo

${ }^{1}$ Texto originalmente publicado em Italiano, em Araújo Jr. e Cornelli, 2012. Agradeço aos organizadores dessa coletânea pela gentil permissão para a publicação em português. 
narrar o que ele disse (Platão, 1991, pp. 105-106).

Parece que Allen está certo, ao chamar a atenção para o papel formal que desempenha Alcibíades. O auto-elogio de Sócrates, de fato, além de retirar força do retrato que Platão está pintando de seu mestre de um ponto de vista que podemos chamar de retórico, certamente não estaria em consonância com esse próprio retrato, que, entre outras coisas, nos apresenta um Sócrates desprovido de ambições relacionadas à reputação e à fama. Sabemos mesmo por outros diálogos platônicos que a filosofia socrática se apresentou como uma forma de crítica a esses valores. Assim, pode-se justificar a presença de Alcibíades - talvez mesmo, como propõe Allen, a de Diotima - como um recurso estilístico necessário à boa construção da figura de Sócrates.

Contudo, isso ainda não é suficiente para responder à pergunta: por que Alcibíades? Pois a razão alegada, na verdade, explica apenas a necessidade de que um outro que não o próprio Sócrates faça o elogio de Sócrates, mas não chega a justificar por que esse outro devia ser Alcibíades. Pode-se simplesmente alegar que a escolha dessa personagem tão controversa da vida ateniense do final do século $\mathrm{V}$ a. C. se deveu a ter sido ele um dos mais próximos companheiros de Sócrates, como talvez um Crítias, um Cármides, um Laques, um Querefonte ou um Apolodoro, os quais Platão também poderia ter escolhido, não o fazendo apenas por acaso. Desses vários indivíduos cujos nomes aparecem associados ao de Sócrates em diferentes diálogos, era preciso decidir-se por apenas um, e a escolha teria recaído então sobre Alcibíades.

Sabemos, no entanto, que essa escolha tem razões bem mais sólidas e filosóficas. O mesmo Allen observa, em seu comentário, que o elogio de Sócrates por Alcibíades é, ao mesmo tempo, 
sua defesa. Isso nos coloca diante da tese difundida e bastante razoável de que esse elogio constitui uma forma de retomada da defesa socrática contra as acusações que finalmente o levaram à morte. Noutros termos, com essas páginas finais do diálogo, Platão retoma a injusta condenação de seu mestre, e sabemos que a tese central da acusação, junto com a suspeita de que Sócrates negara os deuses da cidade, afirma que ele teria, com seu lógos, corrompido os jovens atenienses. Ora, dificilmente se poderia negar que tal acusação deve ter-se baseado no fato de que alguns daqueles seguidores do filósofo se transformariam em agentes da destruição de Atenas, de sua derrocada na Guerra do Pelonopeso e dos acontecimentos nefastos que se seguirão, aí incluídos, sobretudo, Crítias, Cármides e o próprio Alcibíades, que provavelmente aparecia aos acusadores, a boa parte dos juízes e até dos cidadãos, como exemplo paradigmático dos efeitos deletérios do ensino socrático. Não é à toa que Sócrates dirá, na presença de Alcibíades: "Agatão, vê se me defendes! Que o amor deste homem se me tornou um não pequeno problema" $(213 \mathrm{c})^{2}$. Desse ponto de vista, como sugere também o comentário de Allen, o elogio de Eros por Diotima, isto é, a correta compreensão da natureza do amor, pode ser considerado, ao mesmo tempo, uma forma de descrever a maneira como Sócrates compreendera e exercitara suas relações com jovens como Alcibíades. O verdadeiro significado de Eros nos dá o verdadeiro significado da conduta socrática, e o elogio de Alcibíades no final do diálogo mostrará também que ele nunca chegou a compreender plenamente esse significado.

Assim, como esse elogio se dá após a devida compreensão da

\footnotetext{
${ }^{2}$ A tradução citada do Banquete é sempre a de José Cavalcante de Souza, Platão, 1986. Para o texto grego, cf. Platão, 1985.
} 
natureza de Eros, o leitor do diálogo poderá entender o que, afinal, Sócrates pretendera em seu convívio com o jovem ateniense. Com isso, Platão quer nos dizer que, se Alcibíades fez o que fez - além de propor a malograda expedição na Sicília, trair Atenas em favor de Esparta -, isso não pode ser imputado à sua frequentação de Sócrates, a suas relações com o filósofo, que não pode então ser acusado de corrupção da juventude por causa de relacionamentos como esse. Alcibíades não foi político nefasto para Atenas porque conviveu com Sócrates: ele o foi, apesar desse convívio - eis, pode-se dizer, uma das intenções, talvez a intenção maior, do elogio de Sócrates por Alcibíades, e eis por que ele deve ser então o encarregado desse elogio. É como se Alcibíades, em seu discurso ao mesmo tempo carregado de admiração e ressentimento, estivesse agora no tribunal, prestando testemunho diante dos juízes, para lhes apresentar a verdade, ou, ao menos, a sua verdade sobre suas relações com Sócrates, verdade essa que absolve o filósofo, pois nunca pretendeu estimular em seu jovem seguidor ideias que pudessem justificar o comportamento nocivo que teve. Muito ao contrário: diz Alcibíades que, com Sócrates, conheceu a importância de cuidar de si, embora preferisse sempre tratar das coisas da cidade, conduzido pelo desejo da reputação pública (216a-b). Experimentou vergonha por seus atos, embora nunca a ponto de abandonar suas aspirações (216b-c). Conforme descreve suas relações complexas com Sócrates, Alcibíades vai revelando a verdadeira natureza do mestre, esse homem dotado de coragem e temperança, sabedoria e controle $(219 \mathrm{~d})$, que tenta mostrar-lhe a diferença entre o belo aparente e o belo real e verdadeiro (218e). Esse homem a quem ninguém pode se comparar, antigo ou moderno, um homem desconcertante (221c-d), que despreza riquezas, títulos de 
honra e fama (216d-217a) - indivíduo, numa palavra, portador de notável singularidade (215a).

O discurso de Alcibíades pode, então, ser visto como momento final de um amplo movimento de elaboração do sentido filosófico de Eros, que permitirá a Sócrates, por meio do discurso de Diotima, ensinar a seus companheiros de simpósio o que vem a ser o "correto amor aos jovens" (tò orthôs paiderasteîn), que proporciona a visão do Belo (211b), incompreensível para quem não sabe distinguir entre, de um lado, um elogio a Eros que apenas acrescente o máximo à coisa elogiada e dela fale com o máximo de beleza, mesmo que falsamente, e, de outro, um elogio que saiba dizer a verdade sobre o que é elogiado, referindo-se apenas a suas manifestações verdadeiras (198d-e).

Desvelar a natureza de Eros significa, em verdade, compreender o sentido da filosofia. Esta se caracteriza, tal como o deus, como um tipo de intermediário no interior de uma escalada ascensional. Eros é filósofo porque, como todos os que filosofam, ele está no meio da sabedoria e da ignorância, ele é amor do belo e a sabedoria é uma das coisas belas (203e-204b). O filósofo é mensageiro, ele porta e conduz. A filosofia, não sendo ainda sophía, encontra na natureza de Eros forma de expressão de sua própria condição: ambos, Eros e filosofia, têm relações com a carência, com a aporia. Ambos aspiram, por isso, à euporía. O philósophos nutre éros pelo real e pela sophía. Eis aí sua condição intermédia, em busca de plena realização, que somente uma ascese a partir dos corpos, até o saber último, pela alma, deverá proporcionar, ensinando a considerar a beleza das almas como superior à dos corpos (210b) e a ascender pelo caminho que corretamente conduz à perfeita contemplação das verdadeiras coisas do amor (210a), passando de um belo corpo a vários, 
a vários tipos de ocupações e ofícios belos, até aquele belo em si (210a-212a). Com isso se realiza a possibilidade de um ensino real e autêntico, por aquele que foi "desde cedo fecundado em sua alma":

e se encontra uma alma bela (psykhêi kalêi), nobre e bem dotada (gennaíai kai euphyêi), é total seu acolhimento a ambos (alma e corpo), e para um homem desses logo ele se enriquece (euporê̂) de discursos sobre a virtude, sobre o que deve ser o homem bom (tòn ándra tòn agathón) e o que deve tratar, e tenta educálo (paideúein) (209b-c).

Essa concepção de Eros, que fornece fundamento para compreender a conduta socrática, conduta que o elogio de Alcibíades, num misto de indignação e fascínio, descreve como capaz de dominar o mero desejo físico (219b-d), explica a maneira como nosso filósofo entende a difícil tarefa de exercitar sua própria filosofia e o ainda mais difícil desafio de fornecer algum tipo de ensino ou transmissão de saber. E a dificuldade já está posta no início do diálogo, antes mesmo dos diversos discursos sobre Eros, no momento em que, após ter retardado sua entrada na casa de Agatão por causa de um pensamento que ocupara sua mente, Sócrates finalmente chega e ouve do anfitrião o convite: "Aqui, Sócrates! Reclina-te ao meu lado, a fim de que ao teu contato (haptómenós sou) desfrute eu da sábia ideia (tô̂ sophô̂) que te ocorreu em frente de casa" (175c). A tal convite, que aposta no contato físico entre ambos, Sócrates responde nos seguintes termos, ainda irônicos: "Seria bom, Agatão, se de tal natureza fosse a sabedoria (sophía) que do mais cheio escorresse ao mais vazio, quando um ao outro nos tocássemos, como a água dos 
copos que pelo fio de lã escorre do mais cheio ao mais vazio" (175d). Pode-se dizer que o essencial do significado de Eros e de suas consequências para o ensino do filósofo, no discurso de Diotima, se antecipa nessa resposta e encontrará sua confirmação no discurso de Alcibíades, de modo a que se esclareçam as verdadeiras intenções socráticas e o sentido em que entende suas relações com seus jovens interlocutores.

Portanto, pode-se sustentar a tese de que o Banquete, sobretudo na intervenção de Alcibíades, embora não exclusivamente nela, contém uma nova defesa de Sócrates, contra as acusações de que injustamente fora vítima. Mas vejamos até que ponto se pode desenvolver essa ideia. Trata-se aqui de tentar aprofundála, por meio de uma leitura que, destacando alguns momentos do diálogo, possa mostrar como Platão está ainda convidando seu leitor a se voltar para o lugar por excelência de sua afirmação e defesa do socratismo: a Apologia de Sócrates.

$$
* * *
$$

De início, pode-se observar a presença de um vocabulário típico, que ajuda a construir um cenário ou ambiente característico de um julgamento e de um tribunal. E isso já começa a ser feito na resposta que Agatão dará, ao ouvir o comentário de Sócrates, acima citado, sobre a transmissão do saber: "És um insolente (hybristés), ó Sócrates ... Quanto a isso, logo mais decidiremos (diadikasómetha) eu e tu da nossa sabedoria, tomando Dioniso por juiz (dikastêi)". Esta resposta, decerto de maneira superficial e talvez apenas metafórica, alude a um tipo de acusação - a acusação de "insolência" (hybris) -, a um julgamento e a juízes: Agatão, Sócrates e talvez todos os participantes da bebedeira, além do próprio vinho que se consumirá, personifi- 
cado na figura de Dioniso. A ela se seguem outros momentos que reforçam a sugestão de um cenário de tribunal ${ }^{3}$.

Veja-se, por exemplo, o momento que antecede o discurso de Agatão sobre Eros. Expressando preocupação por ter que falar após o jovem poeta, Sócrates dele ouve a resposta: "Enfeitiçar é o que me queres, ó Sócrates..., a fim de que eu me alvoroce (thorybethô) com a ideia de que o público (tò théatron) está em grande expectativa de que eu vá falar bem (hos ê̂ eroúntos emô̂)" (194a). Note-se a mescla de vocabulário teatral e forense, sobretudo o emprego do verbo thorybeîn, que significa também "fazer ruído", "murmurar", sentido provavelmente típico de discursos de tribunal, nos quais se deve "falar bem", como disse Agatão, e que aparece no discurso de Sócrates na ApologiaSócrates solicita aos juízes que não se alvorocem com o que dirá: méte thorybeîn, $17 \mathrm{~d}$; mè thorybésete, 20e; mè thorybeîn, $27 \mathrm{~b}$; mè thorybeîte, 30c. Ou ordena a Meleto que não tumultue: mé...thorybeito, 27b.. A resposta de Sócrates se formula em termos semelhantes, ao descrever a ação de Agatão no teatro, no dia anterior, com vocabulário que bem poderia valer para uma situação de tribunal, onde predomina a exibição retórica:

Desmemoriado eu seria, Agatão, ... se depois de ver tua coragem e sobranceria, quando subias ao estrado com os atores e encaraste de frente uma tão numerosa plateia (tosoútoi théatroi), no momento em que

\footnotetext{
${ }^{3} \mathrm{~A}$ alusão ao tribunal deve também ser observada pela ótica de um julgamento de concurso teatral, sobretudo porque o comentário é de Agatão, poeta que vencera no dia anterior um concurso, o que também permite compreender a alusão a Dioniso. A esse respeito, leia-se a observação de L. Robin à passagem (Platão, 1985, p. 7, n. 1). Mas o vocabulário, aqui como em outras passagens, também leva a pensar num processo jurídico, como se verá.
} 
ias apresentar uma peça tua (epideíxesthai sautô̂ lógous), sem de modo algum te teres abalado, fosse eu agora imaginar que tu te alvoroçarias (thorybethésesthai) por causa de nós, tão poucos (194b).

Também Alcibíades se servirá desse verbo, ao descrever os efeitos nele produzidos pelos discursos socráticos:

Quando com efeito os escuto, muito mais do que aos coribantes em seus transportes bate-me o coração, e lágrimas me escorrem sob o efeito dos seus discursos, enquanto que outros muitíssimos eu vejo que experimentam o mesmo sentimento; ao ouvir Péricles porém, e outros bons oradores, eu achava que falavam bem sem dúvida, mas nada de semelhante eu sentia, nem minha alma ficava perturbada (oud'etethorybetó mou he psykhé) nem se irritava, como se se encontrasse em condição servil (215e).

Há ainda uma breve fórmula característica do tribunal da Apologia, generosamente empregada por Alcibíades em seu elogio de Sócrates. Em seu discurso de defesa, Sócrates se dirigiu a seus juízes e audiência no tribunal pela evocação "homens atenienses" (ốndres Athenaîoi) ${ }^{4}$, às vezes apenas dizendo "homens" (ô ándres) $)^{5}$, além de "homens que me mataram" (ô ándres hoi emè apektónate, 39c) e "juízes" (ô ándres dikastaí, 40a, 40e, 41c). Ora, o discurso de Alcibíades apresenta a formulação ô ándres

\footnotetext{
${ }^{4}$ As referências são bastante frequentes: 17a, 18a, 18c, 18e, 19c, 20c, 20e, 22a, 22d, 24a, 24c, 26a, 26e, 28a, 28d, 29d, 30b, 30c, 31d, 32e, 33c, 34d, $35 \mathrm{~b}, 35 \mathrm{c}, 35 \mathrm{~d}, 36 \mathrm{~b}, 36 \mathrm{~d}, 37 \mathrm{a}, 37 \mathrm{~d}, 38 \mathrm{~b}, 38 \mathrm{c}$.

${ }^{5}$ Ocorrências também numerosas: 19e, 23a, 27a, 27b, 29a, 29b, 31a, 34b, 35b, 38a, 38d, 39a, 39e, 41e.
} 
em vários momentos: 214a, 215a, 215d, 217b, 218b, 220e, 222a. E usa "companheiros de bebida" (ô ándres sympótai) (216d), além de "senhores juízes" (ô ándres dikastaí), acrescentando: "sois com efeito juízes (dikastaí) da sobranceria (hyperephanías) de Sócrates" (219c). E como Agatão já o fizera em tom certamente mais suave, também ele acusa Sócrates de ser "insolente" (hybristés, 215b) ${ }^{6}$.

O próprio Sócrates contribui para essa atmosfera de tribunal familiar à Apologia, quando esclarece o estatuto do elogio de Eros que fará por meio de Diotima:

Não vou mais elogiar desse modo, que não o poderia, é certo, mas a verdade (tà alethê), se vos apraz, quero dizer à minha maneira (kat'emautón), e não em competição com os vossos discursos, para não me prestar ao riso. Vê, então, Fedro, se por acaso há ainda precisão de um tal discurso, de ouvir sobre o Amor dizer a verdade, mas com nomes e com a disposição de frases que por acaso me tiver ocorrido (onomásei dè kai thései rhématon toiaútei hopoía dè án tis t?khei epelthoûsa) (199a-b).

Apesar de evidentes diferenças de contexto - não se trata, no tribunal, de uma competição -, pode-se ao menos perceber forte semelhança com a introdução socrática do tipo de discurso que fará em sua defesa, em contraste com o de seus acusadores, como se espera, aliás, de um bom orador: diferente de seus acusadores, Sócrates dirá "toda a verdade" (pâsan tèn alétheian), e não "discursos 'beletrificados (kekalliepeménous...lógous), nem

\footnotetext{
${ }^{6}$ Diante de uma possível objeção socrática, Alcibíades acrescenta: "Pois se não admitires, apresentarei testemunhas (mártyras)" (215b).
} 
bem ordenados nas expressões e palavras (rhémasi te kaì onómasin...kekosmeménous); vocês vão ouvir sim coisas ditas de improviso (eikêi legómena), com as palavras que me ocorrerem (tô̂s epitykhoûsin onómasi)" (17b-c) $)^{7}$. Sócrates tem razões filosóficas para fazer destoar seu elogio de Eros daqueles feitos por seus companheiros, que são, em linhas gerais, as mesmas que o levavam, no tribunal, a enfatizar que se encontra na mesma situação de um estrangeiro (xénos), em matéria de léxis forense, acostumado com outro tipo de uso do lógos, aquele que, como muitos sabem, ele costumeiramente exercita na ágora (17c-d). Esse procedimento costumeiro, o diálogo, é lembrado por Fedro no Banquete e é por ele visto como um possível obstáculo ao bom andamento da competição de elogios a Eros:

Meu caro Agatão, se responderes a Sócrates, nada mais lhe importará do programa, como quer que ande e o que quer que resulte, contanto que ele tenha com quem dialogue (dialégetai), sobretudo se é com um belo. Eu por mim é sem dúvida com prazer que ouço Sócrates conversar (dialegoménou), mas é-me forçoso cuidar do elogio ao Amor e recolher de cada um de vós o seu discurso (194d).

Em certo sentido, portanto, Sócrates se sente pouco à vontade também entre os elogios a Eros que acaba de assistir, e expressa essa condição antes de iniciar seu elogio. O próprio Alcibíades, em seu elogio, recorrerá ao expediente típico da retórica forense, quando começar a referir-se à recusa de Sócrates de manter re-

\footnotetext{
${ }^{7}$ As citações da Apologia de Sócrates seguem a tradução de Platão, 2008. Para o texto grego, cf. Platão, 1970.
} 
lações físicas com ele, o que lhe causa espanto: "é preciso, com efeito, dizer-vos toda a verdade (pánta talethê)" (217b).

$$
* * *
$$

Até aqui, pode-se dizer que este breve esboço de aproximação entre o elogio de Sócrates no Banquete e seu discurso de defesa na Apologia explorou, sobretudo, elementos de natureza estilística: usos de expressões semelhantes e certos procedimentos discursivos afins. Com isso, sugere-se apenas que a própria doutrina do diálogo mais maduro, tratando da natureza de Eros, fornece elementos para aprofundar as razões em favor da defesa de Sócrates perante as injustas acusações de que foi vítima. Noutros termos, as semelhanças de caráter léxico, aproximando os dois textos, pavimentam o caminho para a tese mais complexa de que a concepção mesma de Eros veiculada por Sócrates no Banquete serve também, como se disse aqui de início, a um esclarecimento do correto sentido de paiderasteîn, de modo a isentar Sócrates de qualquer culpa, no que concerne aos resultados nocivos que uma má educação produziu em jovens como Alcibíades. Para mostrar a presença do tema filosófico, a análise voltou-se para alguns sugestivos pormenores de expressão.

Mas talvez se possa levar mais adiante essa aproximação, observando, no elogio de Alcibíades, a presença de algumas ideias que já haviam sido desenvolvidas na Apologia, com o objetivo de elaborar o retrato do filósofo. Ali, a defesa de Sócrates era ao mesmo tempo a retomada de sua filosofia, apresentada numa versão em que certamente se misturam aspectos do pensamento do mestre e refinamentos devidos ao discípulo, preocupado com recuperar e preservar a excepcional originalidade e riqueza de um filósofo que, mesmo após a morte, continuou a provocar o 
amor e o ódio de seguidores e detratores. Por isso, o discurso de defesa, precisando partir dos equívocos de compreensão da cidade a respeito dessa figura ímpar, tem que fornecer a correta maneira de interpretar um pensador ao mesmo tempo simples, porque trata sempre de exemplos banais e de assuntos quotidianos, compreensíveis, em certo sentido, a qualquer um, e complexo, porque o faz por um prisma inédito e ao mesmo tempo ofensivo aos saberes estabelecidos. Em nenhum momento dessa defesa, se expressa com mais força a singularidade de Sócrates e o verdadeiro significado de sua atitude na cidade, do que no célebre relato sobre o Oráculo de Delfos. Eis o lugar privilegiado, na Apologia, para a compreensão do socratismo, para o entendimento de uma postura de vida e de uma visão de mundo que vai nortear todo o restante do discurso de defesa no tribunal. Pretende-se agora sugerir que, entre esse relato e o elogio de Alcibíades no Banquete, podem-se encontrar algumas analogias e até mesmo, talvez, simetrias filosoficamente profundas.

De fato, Alcibíades descreve sua experiência pessoal de convívio com Sócrates de uma forma que parece mesmo retomar algumas características importantes do retrato socrático, que a narrativa do episódio do Oráculo de Delfos vai, aos poucos, tornando evidente ao ouvinte do tribunal e aos olhos do leitor. Alcibíades deixa claro o que tem em mira, ao procurar Sócrates: "A mim, com efeito, nada é mais digno de respeito do que o tornar-me eu o melhor possível (hóti béltiston emè genésthai), e para isso creio que nenhum auxiliar me é mais importante do que tu" (218d). Ora, eis aí o motivo por excelência, na Apologia, da acusação de "corrupção dos jovens", pois Sócrates aparece à cidade como um dos que ensina a "tornar-se melhor", e a explicação sobre o que vem a ser sua atividade (prâgma, 20c) visa a 
mostrar que, diferente de sofistas como Górgias, Pródico, Hípias e Eveno (19e-20b), e do que se vê no infeliz retrato aristofânico (18b, 19b-c), ele não promete tornar os jovens que o seguem kaloi kai agathoi, "belos e bons", para usar a expressão paradigmática a respeito dessa importantíssima questão relativa à moral grega. Contudo, sem pretender ensinar ninguém, Sócrates se tornou objeto de imitação de muitos jovens ricos (23c). Embora o tema seja explorado também no interrogatório de Meleto a seguir (cf. 24c-25c), ele é visado todo o tempo na narrativa do Oráculo. Quando, então, Alcibíades apresenta seu interesse no convívio com Sócrates naqueles termos, ele nos transporta para o coração da questão que atravessa a defesa socrática na Apologia. E o cerne dessa defesa se encontra na narrativa do Oráculo.

Um ponto de aproximação bastante interessante é sugerido pela célebre imagem das estátuas de silenos, a que recorre Alcibíades para tentar expressar quem realmente, em sua opinião, é Sócrates: "Afirmo eu então que é ele muito semelhante a esses silenos colocados nas oficinas dos estatuários, que os artistas representam com um pifre ou uma flauta, os quais, abertos ao meio, vê-se que têm em seu interior (éndothen) estatuetas de deuses" (215b). É esse interior que nos revela o que nele há de tão especial:

A quem quisesse ouvir os discursos de Sócrates pareceriam eles inteiramente ridículos à primeira vez: tais são os nomes e frases de que por fora (éxothen) se revestem eles, como de uma pele de sátiro insolente! Pois ele fala de bestas de carga, de ferreiros, de sapateiros, de correeiros, e sempre parece com as mesmas palavras dizer as mesmas coisas, a ponto de qualquer inexperiente ou imbecil zombar de seus discursos. 
Quem porém os viu entreabrir-se e em seu interior (entós) penetra, primeiramente descobrirá que, no fundo (éndon), são os únicos que têm inteligência, e depois, que são o quanto possível divinos, e os que o maior número contêm de imagens de virtude, e o mais possível se orientam, ou melhor, em tudo se orientam para o que convém ter em mira, quando se procura ser um distinto e honrado cidadão (kalôi kagathôi). Eis aí, senhores, o que em Sócrates eu louvo (221e-222a).

Esses comentários aludem também à notória feiura exterior de Sócrates, a qual, a julgar pelo que disse Alcibíades, não nos deve enganar, pois seu lógos arrebata mais do que o faria qualquer beleza corporal:

Que esta sua atitude não é conforme à dos silenos? E muito mesmo. Pois é aquela com que por fora (éxothen) ele se reveste, como o sileno esculpido; mas lá dentro (éndothen), uma vez aberto, de quanta sabedoria (póses...sophrosynes) imaginais, companheiros de bebida, estar ele cheio? Sabei que nem a quem é belo tem ele a mínima consideração, antes despreza tanto quanto ninguém poderia imaginar, nem tampouco a quem é rico, nem a quem tenha qualquer título de honra, dos que são enaltecidos pelo grande número; todos esses bens ele julga que nada valem, e que nós nada somos e é ironizando e brincando com os homens que ele passa toda a vida. Uma vez porém que fica sério e se abre, não sei se alguém já viu as estátuas lá dentro (entós); eu por mim já uma vez as vi, e tão divinas me pareceram elas, com tanto ouro, com 
uma beleza tão completa e tão extraordinária que eu só tinha que fazer imediatamente o que me mandasse Sócrates (216d-217a).

É preciso observar a notável densidade dessa passagem, que por assim dizer resume a filosofia socrática tal como transparece da Apologia: uma crítica contundente aos valores relacionados à beleza física, à riqueza, à honra, em favor dos valores do conhecimento, da virtude e da alma. Ela se dá, ainda que por meio de uma simples imagem, mediante uma distinção entre "exterioridade" e "interioridade", também ela filosófica, que vai muito além daquele texto precoce, mas que nele talvez se inspire. Por meio de um Alcibíades, alma naturalmente dotada para a filosofia, mas desviada pelas paixões que seria preciso saber controlar, Platão descreve Sócrates à luz de uma dicotomia que um diálogo como o Fédon explora filosoficamente com grande profundidade, mediante uma distinção forte entre alma e corpo, mas que aqui, no contexto de um elogio feito por um ébrio apaixonado, mas ressentido, apenas aponta para uma ética de valores interiorizados, os quais, no entanto, já se apresentavam em esboço no quadro pintado pela Apologia, sobretudo no episódio do Oráculo. Pois ali, após tomar conhecimento do conteúdo oracular ninguém é mais sábio do que ele -, Sócrates contrasta essa fala divina, que em princípio deve ser aceita como verdadeira, porque divina, com a convicção íntima que traz consigo, a de que nada sabe. Essa convicção é expressa em vocabulário que acentua seu caráter estritamente pessoal e subjetivo - nesse sentido, "interno": "Depois de ouvir aquelas palavras, fiquei refletindo (enethymoúmen) assim: 'O que é que o deus está dizendo, e o que é que está falando por enigma? Pois bem sei comigo mesmo ( $s$ ?noida emautôi) que não sou sábio - nem muito nem pouco" - 
(21b). E toda a investigação que Sócrates fará, para refutar o oráculo, será comentada em termos semelhantes: "Em seguida, fiquei tentando lhe mostrar (a um interlocutor) que ele pensava ser sábio, mas que não era. A partir daí me tornei odioso a ele e a muitos dos circunstantes e, indo embora, fiquei então raciocinando comigo mesmo (pròs emautòn...elogizómen) - 'Sou sim mais sábio do que esse homem..."' (21c-d). E ainda:

Por fim, me dirigi aos técnicos. Sabia comigo mesmo (emautôi synéde) que eu, a bem dizer, não conhecia nada..., de modo que fui perguntando a mim mesmo (me emautòn anerotân) - em nome do oráculo - se eu preferia ser assim como sou, nem sábio na sabedoria deles nem ignorante na ignorância, ou possuir essas duas coisas que eles possuem. Respondi então a mim mesmo e ao oráculo (apekrinámen emautôi kai tôi khresmôi) que seria mais proveitoso para mim ser como sou (22c-d, e).

O Sócrates-sileno retoma, assim, o pensador que se põe em conflito com a fala divina, por valorizar uma atitude reflexiva e subjetiva, e que, conforme investiga aquela fala com o objetivo de refutá-la, vai descobrindo sua verdade e compreendendo que não há, de fato, o conflito inicialmente visto, pois saber que nada sabe, a verdade interior que desde sempre o movera, é sinal de sabedoria, a verdade anunciada pelo oráculo. Operase aí decisiva conciliação entre a interioridade do filósofo e a objetividade inquestionável da verdade divina, conciliação que torna o filósofo, doravante, um auxiliar do deus, um refutador que quer mostrar a seus semelhantes a necessidade de aceitar o caráter ilusório de seus saberes. Alcibíades, pela imagem das 
estátuas dos silenos, aponta para o valor superior que Sócrates dava ao auto-exame, a esse "olhar para dentro", que se consagrou na expressão cuidado de si, que confere ao socratismo toda a sua singularidade e que o filósofo gostaria de ver valorizado também por seus interlocutores. Desse apreço pela inspeção interior, o Banquete nos dá exemplo ainda em seu início, quando Sócrates, "como que ocupando o seu espírito consigo mesmo (heautôi pos prosékhonta tòn noûn), caminhava atrasado, e como o outro se detivesse para aguardá-lo, ele lhe pede que avance" (174d). Comenta Aristodemo: "Mas não! Deixai-o! É um hábito (éthos) seu esse; às vezes retira-se onde quer que se encontre, e fica parado" (175b). Também Alcibíades fará alusão a esse hábito:

Concentrado numa reflexão (xynnoésas), logo se detivera desde a madrugada a examinar uma ideia, e como esta não lhe vinha, sem se aborrecer ele se conservava de pé, a procurá-la. Já era meio-dia, os homens estavam observando, e cheios de admiração diziam uns aos outros: Sócrates desde a madrugada está de pé ocupado em suas reflexões! (220c).

Mas é preciso desenvolver um pouco mais este cotejo dos textos. Se o Sócrates que resulta daquela experiência decisiva da investigação sobre o oráculo entende agora por que é preciso conduzir, mediante interrogações, os pretensos sábios a uma situação aporética, não nos esqueçamos de que ele próprio iniciou esse trajeto movido por uma aporia: "E depois de ficar muito tempo em aporia (polùn khrónon epóroun) (o que será que ele está dizendo?), a muito custo me voltei para uma investigação disso" (21b). Essa aporia experimentada pelo próprio Sócrates, que o coloca em um ímpio confronto com o deus, revela a extra- 
ordinária importância que o filósofo dá a essa interioridade, pois nela está a verdade a que não consegue renunciar - saber que nada sabe -, a ponto de desafiar o oráculo. Observe-se agora que Alcibíades, expondo suas relações com Sócrates, exibe, à sua maneira, que decerto não pode ser simplesmente identificada àquela que encontramos no Sócrates da Apologia, duas características comuns: ele se refere a suas certezas pessoais e íntimas, e formula um estado de aporia para esclarecer como se sentia. Com Sócrates, diz o jovem,

muitas foram as vezes em que de tal modo me sentia que me parecia não ser possível viver em condições como as minhas. E isso, ó Sócrates, não irás dizer que não é verdade. Ainda agora tenho certeza ( $x y$ noid'emautôi) de que, se eu quisesse prestar ouvidos, não resistiria, mas experimentaria os mesmos sentimentos. Pois me força ele a admitir que, embora sendo eu mesmo deficiente em muitos pontos ainda, de mim mesmo me descuido (emautô̂ amelô), mas trato dos negócios de Atenas. A custo então, como se me afastasse das sereias, eu cerro os ouvidos e me retiro em fuga, a fim de não ficar sentado lá e aos seus pés envelhecer. E senti diante deste homem, somente diante dele, o que ninguém imaginaria haver em mim, o envergonhar-me de quem quer que seja; ora, eu, é diante deste homem somente que me envergonho. Com efeito, tenho certeza ( xynoida gàr emautôi ) de que não posso contestar-lhe que não se deve fazer o que ele manda, mas quando me retiro sou vencido pelo apreço em que me tem o público. Safo-me então de sua presença e fujo, e quando o vejo envergonho-me pelo que 
admiti. E muitas vezes sem dúvida com prazer o veria não existir entre os homens; mas se por outro lado tal coisa ocorresse, bem sei que muito maior seria a minha dor, de modo que não sei o que fazer com esse homem (215e-216c).

Nessa passagem revela-se toda a complexidade dos sentimentos de Alcibíades em relação a Sócrates: desprezo, vergonha e fascínio, resultantes do embate entre as aspirações políticas e o amor à honra, de um lado, e, de outro, o reconhecimento da importância do cuidado de si. "Não sei o que fazer com esse homem", diz o jovem, antecipando nessa fórmula, similar a algumas expressões de situações aporéticas nos diálogos socráticos, o vocabulário da aporia que será usado logo a seguir, noutra passagem reveladora do estado complexo em que se vê:

Ora bem, depois disso, que disposição de espírito pensais que eu tinha, a julgar-me vilipendiado, a admirar o caráter deste homem, sua temperança e coragem, eu que tinha encontrado um homem tal como jamais julgava poderia encontrar em sabedoria e fortaleza? Assim, nem eu podia irritar-me e privar-me de sua companhia, nem sabia como atraí-lo. Bem sabia eu, com efeito, que ao dinheiro era ele de qualquer modo muito mais invulnerável do que Ájax ao ferro, e na única coisa em que eu imaginava ele se deixaria prender, eilo que me havia escapado. Embaraçava-me (epóroun) então, e escravizado pelo homem como ninguém mais por nenhum outro, eu rodava à toa (219d-e).

No diálogo, há algumas situações de reconhecimento de incapacidade para responder a uma interrogação: Sócrates a res- 
peito do discurso de Agatão (198a-b), Agatão diante das perguntas de Sócrates (201b-c), Sócrates perante Diotima (204d, 206b, 207c). Elas colaboram para a valorização do método tipicamente socrático da interrogação, em detrimento dos discursos mais longos. A aporia de Alcibíades, contudo, é por assim dizer existencial, e não simplesmente parte de uma interlocução qualquer. Não à toa, o jovem a apresenta com todo o seu peso e dramaticidade. Trata-se, para ele, de uma divisão interna entre inclinações inconciliáveis.

Pode-se dizer que Alcibíades tem certezas a respeito de Sócrates e do valor superior de seu lógos, e que isso produzia nele sentimentos favoráveis a adotar um modo de vida e uma atitude filosófica como a que, a julgar pela Apologia, Sócrates propunha a seus interlocutores: aprendendo a pôr em questão seus falsos saberes, de algum modo exercitar o cuidado do pensamento, da verdade e da alma, em detrimento do dinheiro, da fama e a honra (29d-e, 30a-b, 31b, 36c). Ocorre que nosso jovem traz em si também um forte apelo desses valores que Sócrates critica, o que o torna inevitavelmente portador de uma aporia ${ }^{8}$. Por essa

\footnotetext{
${ }^{8} \mathrm{~A}$ condição em que se encontra aqui Alcibíades é interessante e complexa: ele tem certezas sobre o poder que exerce sobre suas afecções o discurso socrático e chega mesmo a reconhecer que seus desejos por honra pública não são dignos. Mas isso não parece suficiente para uma decisão em favor de uma nova atitude, consoante às recomendações de Sócrates. Cabe perguntar se estamos perante um caso ilustrativo de uma "psicologia socrática" de teor "intelectualista", segundo a qual, grosso modo, somente o saber proporcionaria tal mudança, mesmo porque, nessa hipótese, o saber inevitavelmente a produziria - e nesse caso o que Alcibíades "sabe" não é, a bem dizer, um saber stricto sensu -, ou de uma "psicologia platônica", mais arejada talvez, segundo a qual podemos desejar coisas que sabemos e reconhecemos serem más, à maneira, sobretudo, da teoria da alma tripartida de República $I V$. Embora sempre se possa discutir em que medida semelhante distinção deve ser aceita e adotada, é inegável que a personagem Alcibíades
} 
razão, parece possível perceber, em seu discurso, uma espécie de analogia ou simetria entre a relação que há, no Banquete, entre ele e Sócrates, e a relação que havia, na Apologia, entre Sócrates e o deus. Assim como Sócrates é movido por uma aporia em face do deus, Alcibíades se reconhece em aporia perante Sócrates. Assim como o deus oferece a Sócrates as condições para vencer essa aporia, Sócrates as oferece a Alcibíades. E, deve-se concluir, assim como Sócrates foi capaz de compreender a verdade divina e sua plena consonância com aquela verdade interior que o movia, assim também a Alcibíades são dadas as condições de compreender os benefícios do ensino socrático, de modo a harmonizar sua natural inclinação à filosofia com os valores realmente associados a ela.

Contudo, essa simetria, se simetria houver, deverá ser apresentada com cautela, pois não é o caso de afirmar que nos dois episódios temos exatamente as mesmas peripécias e o mesmo desfecho. A intenção da narrativa sobre o Oráculo de Delfos era construir a figura do filósofo, paradigmaticamente encarnada em Sócrates, que nos deve mostrar as linhas de força de sua filosofia: a exigência da investigação interrogativa mediante o diálogo, o elogio da reflexão interior, o cuidado da alma. O desfecho feliz de uma sequência de fatos que se inicia tensa, a descoberta de que a verdade humana não conflita com a verdade divina, de modo a que a primeira tivesse que ser desqualificada, e a consequente consciência de que o filósofo é um auxiliar do deus, tudo isso serve a um propósito certamente encomiástico, mas que não se limita a ser uma peça de tribunal, consistindo ainda em po-

do Banquete conduz o leitor a uma questão como essa, que aqui fica apenas apontada. Para uma defesa da tese de que, com Alcibíades do Banquete, se trata ainda de uma "psicologia socrática", cf. Rowe, 2006, sobretudo pp. $13-14,19,21$. 
derosa construção filosófica. No Banquete, Alcibíades também faz um elogio de Sócrates, mas uma espécie de elogio à revelia, um reconhecimento constrangido da inevitável verdade sobre o filósofo que o antigo aprendiz não pode negar, mas a que, ao mesmo tempo, não quer aderir. Nesse sentido, a aporia de Alcibíades está condenada à perpetuação: faltam-lhe as condições para dar o passo final na direção da filosofia, porque nele são fortes as paixões. Alcibíades sabe de tudo isso, ele tem consciência do quanto há de benéfico na proposta socrática, mas isso não basta para convertê-lo num verdadeiro discípulo do mestre. Ele está condenado a ter, com esse mestre recusado, uma relação desagradavelmente complexa e, por isso, aporética.

Nada disso, contudo, torna a aproximação menos pertinente. Pois Platão pode ter se servido do mesmo esquema presente no episódio do Oráculo, aplicando-o agora no discurso de Alcibíades, com intenções diferentes. Era preciso mostrar que a experiência de Sócrates com o deus, tendo-o transformado naquele filósofo que a Apologia retrata e recomenda, passa a estar, para ele, no horizonte de toda interrogação aporética. Sócrates quer que seus interlocutores acolham, como ele, a verdade divina. Isso auxiliava no estabelecimento da tese de que Sócrates, ao mesmo tempo em que não era ímpio, não corrompia os jovens. No Banquete, o recurso à interioridade e à aporia não mais serve ao propósito da construção da figura do filósofo, apenas à reiteração da inocência desse filósofo a respeito daquela mesma acusação. Para tanto, o elogio de Alcibíades retoma as linhas gerais do mesmo enredo, para chegar a um desfecho necessariamente distinto: Alcibíades não foi corrompido por Sócrates, porque, tal como Sócrates em face do deus, ele teve a oportunidade de repetir a trajetória que o filósofo fizera, com a 
diferença de que, em vez de fazê-lo sob os olhares do deus, estaria sob a proteção do próprio Sócrates, que é, agora o sabemos, um auxiliar do deus.

Nessa interpretação do elogio de Alcibíades, nota-se como, mais uma vez, Platão faz o elogio de Sócrates: na simetria proposta, Sócrates faz as vezes do deus, em completa consonância com a tarefa que, na Apologia, o filósofo a si mesmo reservara.

$$
* * *
$$

Se tudo isso fizer sentido, essa "defesa de Sócrates" no Banquete, sensível, sobretudo, no elogio de Alcibíades, não mais poderá ser vista como um episódio isolado no diálogo, espécie de posfácio a um estudo sobre Eros, no qual Platão aproveitaria a oportunidade para mais uma vez propor a absolvição do mestre à posteridade. A elaboração de uma "teoria platônica do amor", se quisermos empregar uma expressão forte, evolui pari passu com o desenho do retrato socrático, que, no Banquete e em certos outros diálogos fundamentais, coincide com o retrato do filósofo. Nisso, o Banquete pode ser visto como uma nova versão, certamente mais refinada, daquilo que, na Apologia, Platão apresentava no episódio do Oráculo de Delfos. A missão socrática da Apologia se diz agora sob o signo do Eros-Filósofo do Banquete ${ }^{9}$.

\footnotetext{
${ }^{9}$ Para uma análise que relaciona a imagem das estátuas de silenos com a posição socrática de reconhecimento de ignorância na Apologia de Sócrates, cf. Reeve, 2006, que vê nessa posição uma explicação para o fato de Sócrates declarar-se, no Banquete, conhecedor nas "questões do amor" ( tà erotiká) (177d): seu poder questionador, que aplica sobre si próprio e recomenda a seus interlocutores, o torna um "amante da sabedoria", no sentido do Banquete, e esse poder de "produzir amor" é o que ele, como dádiva divina aos homens, por todo o tempo exercita e vive (cf. sobretudo p. 135).
} 
Nesse sentido, não será absurdo concluir que não somente o elogio de Alcibíades, mas todo o Banquete, o diálogo em sua inteireza, é, afinal, uma nova "apologia de Sócrates". Mesmo que se veja nisso apenas uma tese trivial, tentou-se aqui sugerir que ela não deixa de ser, contudo, profunda e significativamente verdadeira. Desse ponto de vista, o elogio de Alcibíades, por mais que nos possa aparecer simplesmente como uma peça cômica, coroa o estabelecimento de uma ligação indissolúvel entre a missão socrática e o verdadeiro amor.

\section{Referências bibliográficas}

ARAÚJO JR, A.; CORNELli, G. (org.). Il simposio di Platone: un banchetto di interpretazioni. Napoli: Loffredo, 2012. LESHER, J.; NAILS, D.; SHEFFIELD, F. (org.). Plato's Symposium. Issues in Interpretation and Reception. Harvard University Press, 2006.

PLATÃO. Apologie de Socrate. Texte établi et traduit par M. Croiset. Paris: Les Belles Lettres, 1970.

- Le Banquet. Texte établi et traduit par L. Robin. Paris: Les Belles Lettres, 1985.

valcante de Souza. São Paulo: Difel, 1986.

___. The Symposium. Translated with comment by R. E. Allen. Yale University Press, 1991.

- Apologia de Sócrates. Tradução, introdução e notas de André Malta. Porto Alegre: LPM, 2008.

REEVE, C. D. C. "A Study in Violets: Alcibiades in the Symposium". In: LESHER et alii, 2006.

ROWE, C. "The Symposium as a Socratic Dialogue". In: LESHER et alii, 2006. 
